\title{
Impact or push-off lameness presentation is not altered by the type of track surface where horses are trotted
}

\author{
[Claudicação de impacto ou elevação não é alterada pelo tipo de superfície \\ onde os cavalos são troteados] \\ M.S. Azevedo ${ }^{1}$, F.D.D.L. Côrte ${ }^{1}$, K.E. Brass ${ }^{1}$, M. Gallio ${ }^{1}$, S.L. Dau ${ }^{1}$, R. Pozzobon ${ }^{2}$, \\ M.A.F. Lopes ${ }^{3}$, L.F.D. Lopes ${ }^{1}$ \\ ${ }^{1}$ Universidade Federal de Santa Maria - Campus Camobi- Santa Maria, RS \\ ${ }^{2}$ Universidade Federal do Pampa - Uruguaiana, RS \\ ${ }^{3}$ College of Veterinary Medicine - Missouri, USA
}

\begin{abstract}
This study aimed to evaluate the influence of the track surface on which horses are examined, regarding the phase of lameness presentation. Ten horses with lameness in at least one limb were evaluated with wireless inertial sensors on three track surfaces (concrete, loose sand and grass). Six crossover track sequences were established. The variables vector sum, maximum and minimum height of the head and pelvis, variation coefficient of the maximum and minimum height of the head and pelvis were analyzed using ANOVA, followed by Tukey test to compare means between track surface and sequence, at $5 \%$ significance level. The lameness phase (impact or pushoff) was analyzed considering the proportion of affected animals. There were no differences on vector sum, maximum and minimum height or variation coefficient of head and pelvis. Difference was observed on the number of strides registered on sand compared to grass and concrete $(\mathrm{p}<0.0001)$ for fore and hindlimbs. Impact lameness on forelimbs was presented by a larger number of animals on the concrete surface; pushoff lameness was more evident on the grass surface. In the hindlimbs, impact lameness was more evident on the grass surface, while pushoff lameness was in greater number of animals on concrete surfaces. The track sequence on which horses were trotted during evaluation does not seem to be a factor, but the number of lame horses and the phase of lameness manifestation can vary between track surfaces, as some horses showed impact lameness on soft ground and elevation lameness on hard ground.
\end{abstract}

Keywords: horse, impact lameness, lameness locator, objective evaluation, push-off lameness

\section{RESUMO}

Este estudo teve como objetivo avaliar a influência do tipo de superfície em que os cavalos são examinados em relação à fase de apresentação da claudicação. Dez cavalos com claudicação em pelo menos um dos membros foram avaliados com sensores inerciais sem fio em três tipos de superfície (concreto, areia e grama). Seis sequências de cruzamento de tipo de superfície foram estabelecidas. As variáveis soma vetorial, altura máxima e mínima da cabeça e da pélvis, o coeficiente de variação da altura máxima e mínima da cabeça e da pélvis foram analisadas utilizando uma Análise de Variância, seguida do teste de Tukey para comparação das médias entre tipos de superfície e sequências, a um nível de significância de 5\%. A fase da claudicação (impacto ou elevação) foi analisada considerando a proporção de animais afetados. Não houve diferença na soma vetorial, altura máxima ou mínima e coeficiente de variação da altura máxima e mínima da cabeça e pélvis. Foi observada diferença no número de passos registrados na areia em comparação com grama e concreto $(p<0,0001)$ para membros torácicos e pélvicos. Claudicação de impacto nos membros torácicos foi apresentada em um número maior de animais na superfície de concreto, já claudicação de elevação foi mais evidente na superfície de grama. Em membros pélvicos, a claudicação de impacto foi mais evidente na superfície de

Recebido em 24 de maio de 2015

Aceito em 19 de junho de 2015

E-mail: socram_vet@yahoo.com.br 
grama, enquanto claudicação de elevação esteve em maior número de animais na superfície de concreto. A sequência de superfícies em que os cavalos foram troteados durante a avaliação não foi um fator importante na manifestação da claudicação, mas o número de cavalos claudicantes e a fase de manifestação da claudicação podem variar entre as superfícies, visto que alguns cavalos mostraram claudicação de impacto em solo macio e claudicação de elevação em solo duro.

Palavras-chave: cavalo, claudicação de impacto, lameness locator, avaliação objetiva, claudicação de elevação

\section{INTRODUCTION}

Musculoskeletal injuries are a common health problem in athletic horses, and the lesions have a significant relationship with the sport discipline (Smith et al., 2011). Type and condition of track surface on which horses are exercised also directly affect performance and predisposition to musculoskeletal injuries in these animals (Nigg and Segesser, 1988; Williams et al., 2001).

The tensile and deformation strengths which act on the horse during exercise differ according to physical and structural track surface properties (Burn, 2006; Gustas et al., 2006; Burn and Usmar, 2007) and to the sport discipline in which the horses compete. The surfaces used for training and racing thoroughbred horses have a significant impact on the risk of injury (Cheney et al., 1973; Parkin et al., 2004; Perkins et al., 2005); an example is that horses exercised/trained on packed dirt surface are 2.5 times more likely to develop dorsal metacarpal disease (Moyer et al., 1991), a clinical manifestation of stress fractures. In contrast, dressage horses that commonly exercise and compete on loose sand surfaces have a higher incidence of injuries in the suspensory ligament of the hindlimbs (Murray et al., 2006).

The track surface used during the lameness exam is particularly important, since some types of lameness can be exacerbated or attenuated on hard surfaces and others on soft surfaces (Ross, 2011). Soft surfaces that allow a greater sinking/immersion of the hoof in the ground predispose to a high variety of soft tissue injuries that could be related to fatigue. Some of these injuries are fetlock desmitis of the suspensory ligament, superficial digital flexor tendonitis, inferior accessory ligament desmitis and gluteal myositis. On the other hand, hard surfaces predispose to injuries like hoof, joint, bone lesions and pain in the axial skeleton (Maher and Snyder, 2011).
The aim of this study was to evaluate objectively, through body mounted wireless inertial sensors, the possible influence of different track surfaces on which horses are examined on the type of lameness (impact or push off), as well as assess if there is influence of the track sequence in which tests are performed.

\section{MATERIALS AND METHODS}

An approval from Committee on Animal Research and Ethics for this project was obtained from Federal University of Santa Maria (UFSM) (number 042/2014).

Ten horses ( 5 geldings, 5 mares; mean age $11 \pm 5$ years; body mass $407,5 \pm 47 \mathrm{~kg}$ ) of different sport modalities ( 2 jumping, 3 polo, e 5 hippo therapy) were used in this study. The inclusion criteria in the study were based on the identification of lameness through a commercial wireless inertial sensor system (Lameness Locator ${ }^{\mathrm{TM}}$, Equinosis, United States) in at least one of the limbs during the first trot sequence. Some of these horses showed compensatory lameness, which also were included in the assessment.

The animals underwent lameness examinations at a trot, on three different surfaces (concrete, loose sand and grass) (Fig. 1). Six test sequences were established. Sequence 1(SEQ 1) consisted of trotting on concrete, loose sand and grass; sequence 2 (SEQ 2) loose sand, concrete and grass; sequence 3 (SEQ 3) grass, concrete and loose sand; sequence 4 (SEQ 4) loose sand, concrete and grass; sequence 5 (SEQ 5) concrete, grass and loose sand; sequence 6 (SEQ 6) grass, loose sand and concrete. The order of the sequences was determined at random as follows: SEQ 1, SEQ 4, SEQ 3, SEQ 2, SEQ 5 and SEQ 6 . Each horse trotted one sequence in the morning and another in the afternoon. A standard 5-minute interval was established between each surface exam. 


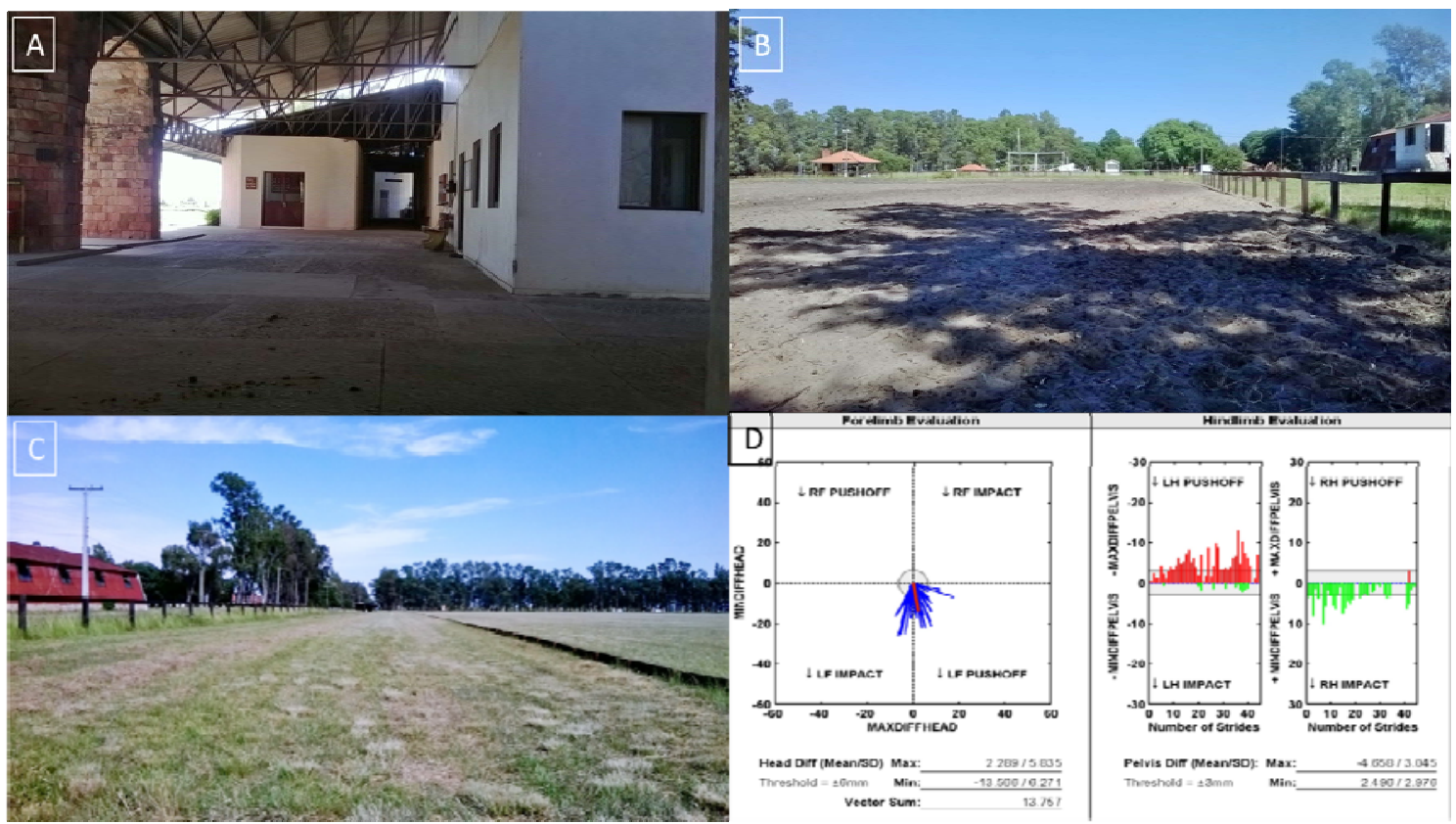

Figure 1. A) Concrete surface; B) Loose sand surface; C) Grass surface, and D) Chart generated by wireless inertial sensor system software (Lameness Locator ${ }^{\mathrm{TM}}$, Equinosis, United States) showing one horse with push-off lameness on the left forelimb (red line on the left chart represents Vector Sum and maximum values of HDmax positive, and HDmin negative); and push-off lameness on the left hindlimb (red columns above threshold on the right chart, PDmax negative and PDmin positive).

All animals were instrumented with three inertial sensors: an accelerometer at the poll region, other accelerometer on the dorsal midline between the sacral tuberosities and a gyroscope on the dorsal aspect of the pastern of the right forelimb. The sensors measure the vertical acceleration of head and pelvis and the angular velocity of the right forelimb digit. After instrumentation, the horse was trotted on a straight line and on a flat surface. Each analysis consisted of trotting the horse for a distance of 25-30 meters and coming back (total distance 5060 meters).

The data collected (at a frequency of 200 measurements per second) were transferred in real time via Bluetooth to a laptop computer where specific software performed data analysis. This analysis included calculation of the following variables: vector sum (VS) that represent the mean difference of maximum (HDmax) and minimum height (HDmin) of the head; HDmax of forelimbs (mean and standard deviation) is the difference between the highest point of the head after support on the right forelimb and the highest point of the head after support on the left forelimb; HDmin of forelimbs (mean and standard deviation) corresponds to the difference between the lowest point of the head while support on the right forelimb and the lowest point of the head during support on the left forelimb. PDmax of hindlimbs (mean and standard deviation) correspond to the difference between the highest point of the pelvis after support on the right hindlimb and highest point of the pelvis after support on the left hindlimb; PDmin of hindlimbs (mean and standard deviation) is the difference between the lowest point of the pelvis during support on the right hindlimb and the lowest point of the pelvis during the support on the left pelvic limb. The data obtained by the gyroscope positioned on the right forelimb digit served to detect the position of the right forelimb digit and infer the position of each member once the trot is a symmetrical gait in which the horse's limbs move in diagonal pairs. Forelimb lameness was observed when VS was greater than the threshold $(8.5 \mathrm{~mm})$, HDmax and/or HDmin, greater than $6 \mathrm{~mm}$ and the standard deviation lower than the average. The hindlimb was considered lame when PDmax and/or PDmin had an average higher than $3 \mathrm{~mm}$ 
and the standard deviation was below the average. The variation coefficient (CV) was established by dividing the standard deviation by the mean of each of the respective variables (HDmax, HDmin, PDmax, PDmin), however when the mean was less than the reference value, division was made by the standard deviation reference value (6 or $3 \mathrm{~mm}$ for forelimbs or hindlimbs, respectively). For statistical calculation, we used the absolute value CVmaxh, CVminh, CVmaxp, CVminp. The classification of lameness phase (impact or push off) was performed by reviewing the chart generated by the software (Lameness Locator ${ }^{\mathrm{TM}}$, Equinosis, United States) (Fig. 1).

Statistical analysis was performed using commercially available software (Statistical Analysis System, version 9). To analyze

A

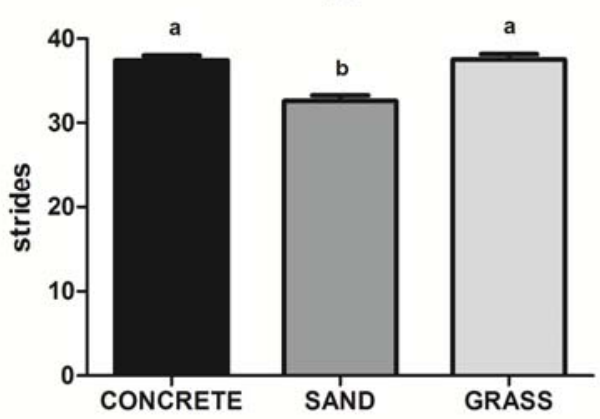

continuous variables (HDmax, HDmin, VS, PDmax, PDmin, CVmaxh, CVminh, CVmaxp and CVminp) ANOVA was followed by Tukey test to compare the means between the different surfaces and between the surface sequences. The significance level was $5 \%$. Data are presented as mean \pm sd.

\section{RESULTS}

The number of strides collected during the evaluation on the sand floor was lower ( $p$ $<0.0001)$ than on other types of surface for both forelimbs and hindlimbs (Fig. 2).

The frequency of lameness by the affected limb, stride phase (impact or push-off), type of ground surface and test sequence performed is presented on Tab. 1.

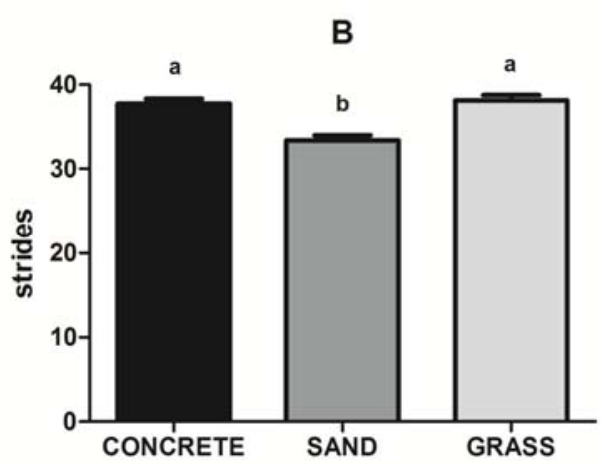

Figure 2. Graphic showing the forelimb (A) and hindlimb (B) strides of horses according to the surface evaluated.

Table 1. Frequency of lame horses according to affected limb, phase of lameness (impact or push-off), type of surface (C: concrete; S: loose sand; G: grass) and sequence of exams

\begin{tabular}{|c|c|c|c|c|c|c|c|c|c|c|c|c|c|c|c|c|c|c|c|}
\hline & \multirow{2}{*}{$\begin{array}{l}\text { Sequence } \\
\text { Surface }\end{array}$} & \multicolumn{3}{|c|}{1} & \multicolumn{3}{|c|}{4} & \multicolumn{3}{|c|}{3} & \multicolumn{3}{|c|}{2} & \multicolumn{3}{|c|}{5} & \multicolumn{3}{|c|}{6} \\
\hline & & $\mathrm{C}$ & $\mathrm{S}$ & $\mathrm{G}$ & S & $\mathrm{C}$ & $\mathrm{G}$ & $\mathrm{G}$ & $\mathrm{C}$ & $\mathrm{S}$ & $\mathrm{S}$ & $\mathrm{G}$ & $\mathrm{C}$ & $\mathrm{C}$ & $\mathrm{G}$ & $\mathrm{S}$ & $\mathrm{G}$ & A & $\mathrm{C}$ \\
\hline Forelimbs & & & & & & & & & & & & & & & & & & & \\
\hline Impact & & 6 & 4 & 4 & 5 & 7 & 3 & 7 & 6 & 7 & 7 & 7 & 7 & 7 & 5 & 5 & 7 & 6 & 5 \\
\hline Push off & & 0 & 3 & 3 & 1 & 1 & 4 & 3 & 2 & 1 & 0 & 2 & 2 & 2 & 5 & 1 & 1 & 1 & 2 \\
\hline Hindlimbs & & & & & & & & & & & & & & & & & & & \\
\hline Impact & & 3 & 2 & 5 & 4 & 2 & 4 & 4 & 3 & 4 & 4 & 4 & 3 & 4 & 4 & 4 & 4 & 4 & 5 \\
\hline Push off & & 3 & 1 & 3 & 1 & 5 & 4 & 4 & 6 & 2 & 2 & 4 & 5 & 3 & 3 & 2 & 4 & 1 & 3 \\
\hline Total & Surface & $\mathrm{C}$ & $\mathrm{S}$ & $\mathrm{G}$ & & & & & & & & & & & & & & & \\
\hline Animals & & & & & & & & & & & & & & & & & & & \\
\hline Forelimbs & & & & & & & & & & & & & & & & & & & \\
\hline Impact & & 38 & 34 & 33 & & & & & & & & & & & & & & & \\
\hline Push off & & 9 & 7 & 18 & & & & & & & & & & & & & & & \\
\hline Hindlimbs & & & & & & & & & & & & & & & & & & & \\
\hline Impact & & 20 & 23 & 25 & & & & & & & & & & & & & & & \\
\hline Push off & & 26 & 9 & 22 & & & & & & & & & & & & & & & \\
\hline
\end{tabular}


On the concrete surface a higher incidence of impact forelimb lameness was detected than on loose sand and grass surfaces (38/34/33, respectively), without considering a possible influence of test sequence. Assessments of pushoff lameness on forelimbs were more frequent on grass surface than on concrete and loose sand surfaces (18/9/7, respectively). The hindlimb evaluation revealed predominance of impact lameness on the grass surface, followed by loose sand and concrete surfaces (25/23/20, respectively). Evaluations of push-off lameness on the hindlimbs showed a higher number of

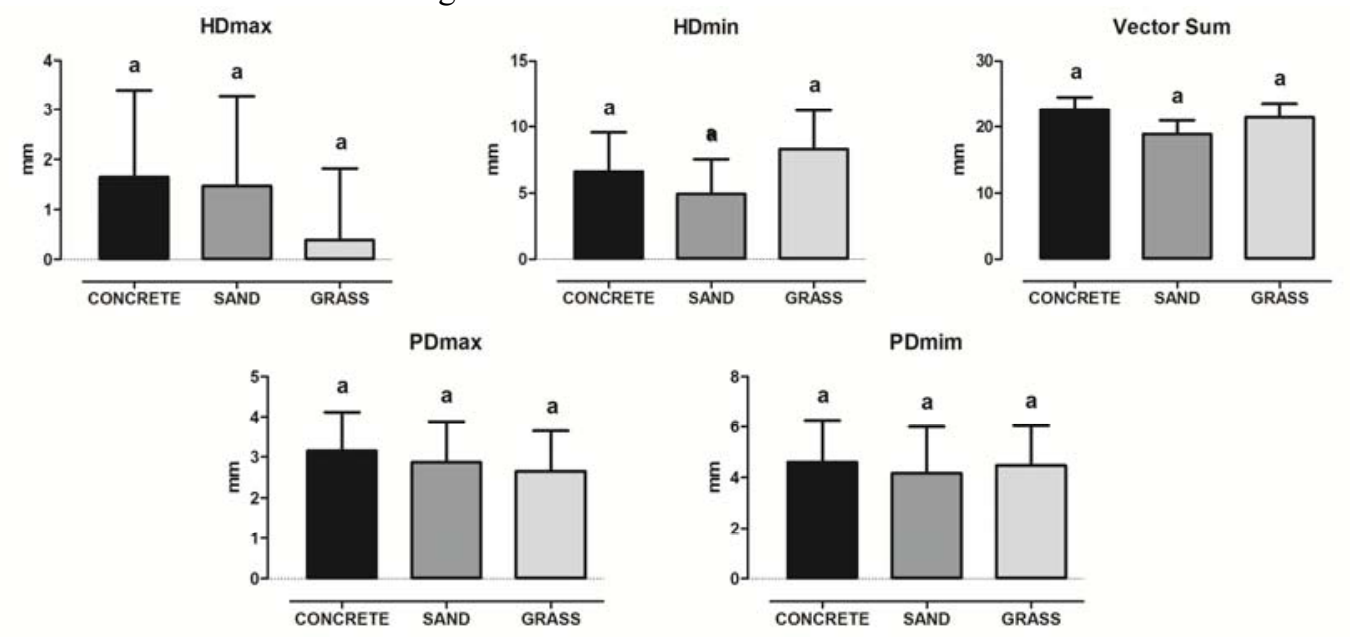

lame horses on the concrete surface compared to grass and loose sand surfaces (26/22/9, respectively).

Continuous variables HDmax, HDmin, VS, PDmax, PDmin, CVmaxh, CVminh, CVmaxp and CVminp showed no difference $(\mathrm{P}>0.05)$ between track surfaces. There was also no influence of the sequence of gait examination on the results of HDmax, HDmin, VS, PDmax and PDmin (Fig. 3), CVmaxh, CVminh, CVmaxp and CVminp (Fig. 4).

Figure 3. Graphic showing HDmax, HDmin and VS of forelimbs and PDmax and PDmin of hindlimbs, in horses, according to the surface evaluated.

A

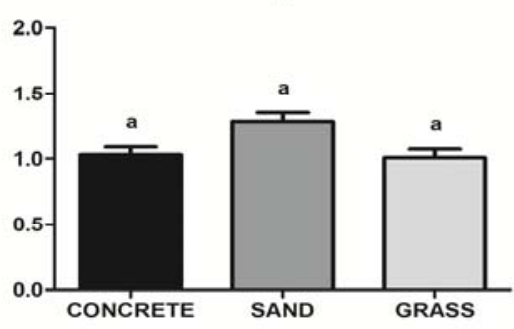

C

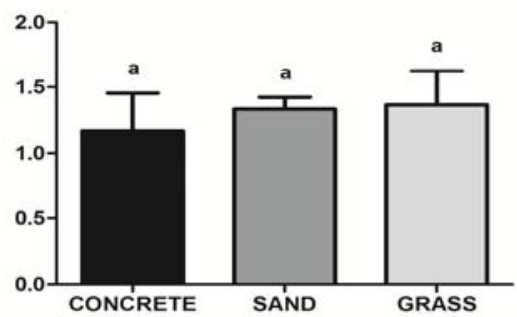

B

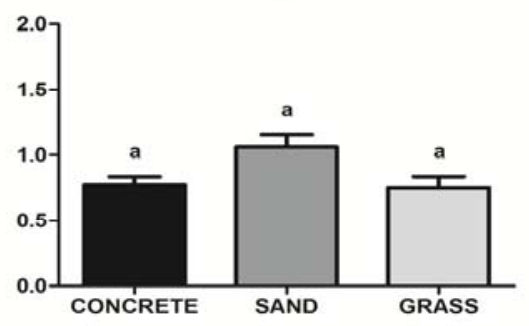

D

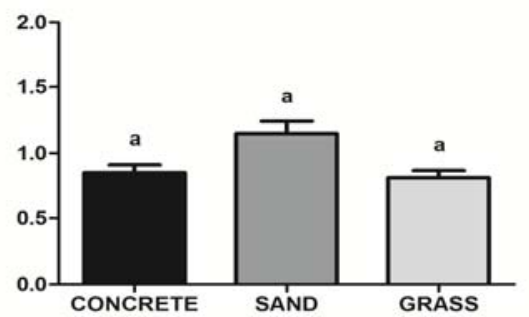

Figure 4. Graphic showing CVmaxh (A), CVminh (B) of forelimbs and CVmaxp (C), CVminp (D) of hindlimbs, in horses, according to evaluated surface. 


\section{DISCUSSION}

The present study aimed to investigate the possible influence of the track surface on which horses were examined over the impact and pushoff lameness when evaluated by a computerbased system with known efficiency and repeatability. Several studies have been conducted previously with these body-mounted inertial sensors for evaluation of flexion tests, the effect of anesthetic drugs, but no study has been performed to analyze whether ground surface has an influence on the lameness exam results (Marshall et al., 2012; Azevedo et al., 2014; Rungsri et al., 2014). The first objective was to verify if the inertial sensors could detect a significant change when animals were evaluated on three different ground surfaces and if different sequences of surfaces on which horses are examined could have an effect on the results. No difference $(\mathrm{P}>0.05)$ was observed between VS, HDmax, HDmin, PDmax, PDmin, CVmaxh, CVminh, CVmaxp and CVminp regardless the surface on which horses were examined, neither the surface sequence used during the exam. This result has an important role on the clinical gait examination, allowing the lameness exam to be initiated on any type of surface independently of clinical suspicion and type of lameness. In addition, no difference in variability was observed between different track surfaces and sequences. The surface on which the test is performed depends on the clinician's preference and the availability of different surfaces for such procedure at a time. Some clinicians prefer harder surfaces like asphalt and concrete for the gait exam, since this condition causes a greater impact that could exacerbate subtle lameness (Ross, 2011). The choice of soft or deeper surfaces would be preferable to exacerbate soft tissue lameness (Maher and Snyder, 2011).

The difference observed in the number of strides listed for the sand surface compared to other surfaces can be related to the speed as the animal trots during the test, so the higher the speed, the lower the number of strides listed for the same distance. Studies done using kinematic analysis have shown that the animals get higher speeds when trotted on a sand surface than when trotted on an asphalt surface, probably due to the reduction in stance phase time and an increase in stride length (Chateau et al., 2010; Chateau et al., 2013). Although the coefficient of variation
(CV) has not differed between the track surfaces, it can be seen that the $\mathrm{CV}$ was higher on the sand surface, which leads to greater variability assessment during the examination on this type of surface.

A definitive diagnosis of the horses selected for this study was not established; the classification of impact or push-off lameness was elaborated based on results of HDmax, HDmin, PDmax and PDmin and evaluation of the charts generated by dedicated software. Previous studies showed that the phase of forelimb lameness is established by analyzing HDmax values, where values greater than $+6 \mathrm{~mm}$ represent impact lameness on the right forelimb or push-off on the left forelimb, and values lower than $-6 \mathrm{~mm}$ represent impact lameness on the left forelimb or elevation on the right forelimb. On the other hand, HDmin enables identification of the lame limb, where values greater than $+6 \mathrm{~mm}$ represent lameness of the right forelimb and values greater than $-6 \mathrm{~mm}$ lameness of the left forelimb. PDmax represents push-off lameness where values over $+3 \mathrm{~mm}$ correspond to the right hindlimb and values lower than $-3 \mathrm{~mm}$ to the left hindlimb. PDmin means values greater than $+3 \mathrm{~mm}$ correspond to right hindlimb impact lameness and values lower than $-3 \mathrm{~mm}$ the left hindlimb (Keegan, 2010).

Ground surfaces like asphalt and concrete have a greater probability to cause impact lameness. Hard surfaces like these generate maximal concussion and thus worsening of a subtle lameness or predisposes to the development of joint, bone and hoof injuries (Maher and Snyder, 2011; Ross, 2011). Similar results were observed in our study considering only forelimb lameness, a greater number of animals showed impact lameness during examination on concrete surface than on the other two surfaces. Literature reports that soft surfaces predispose horses to a variety of soft tissue injuries such as desmitis and tendonitis (Maher and Snyder, 2011). The results observed in the present study demonstrate that this affirmative is not always true, since a greater number of horses showed push-off lameness when trotted on grass than when trotted on loose sand, which appears to be the softest surface. Studies demonstrated that at the end of the stance phase (push- off/propulsion) the load on the superficial digital flexor tendon is significantly affected by the ground surface, and the load is greater on the loose sand than on the asphalt 
surface. Horses suffering from tendon injuries usually do not demonstrate improvement in lameness when examined on soft ground (Crevier-Denoix et al., 2013). One explanation for a higher incidence of push-off lameness in horses on grass compared to loose sand is the presence of organic matter, which strongly influences density of the grass and thus ground compaction (Baker et al., 1998; Saffih-Hdaki et al., 2009). However, in the authors' opinion, the grass surface used in this study did not present such features.

Hindlimb impact lameness was observed in a larger number of horses trotting on grass surface than on the others, which represents just the opposite to the concept that impact lameness initiates on hard surfaces such as concrete (Ross, 2011). A possible explanation is the fact that some grass surfaces may present a high degree of compaction over time, increasing the density and hardness of the surface (Brosnan et al., 2009; Saffih-Hdaki et al., 2009). Likewise, push-off lameness was more prevalent in horses trotting on the concrete surface, which is the opposite of what would be expected considering the literature about push-off lameness or hard surfaces (Ross, 2011). The data reported that some hindlimb lameness could be compensatory to forelimb lameness. Kinematic studies demonstrated that horses with induced lameness in the forelimb decreased displacement and acceleration of the sacral tuberosity when the lame fore and contralateral hindlimb were in the stance phase. This condition generates a false lameness on contralateral pelvic limb that may be apparent (Buchner et al., 1996).

More studies are needed to assess the influence of the ground surface considering the type of injury that the horse presents (tendon and ligament structures versus bone and joint structures).

\section{CONCLUSIONS}

The results of this study demonstrated that the motion exam could be performed on any of the surfaces used without a predetermined sequence, since there was no difference in the variables of the objective evaluation. However, examination on the sand surface provides fewer strides collected by the system than for the same distance on other surfaces.

\section{ACKNOWLEDGEMENTS}

The authors wish to thank Dr. Lucas Campara, DVM and Dr. Guilherme Freitas, DVM Brazilian Army Cavalry Division - Uruguaiana$\mathrm{RS}$, for their contribution to this study. CAPES and UFSM/FATEC agreement CT 124/2014 funded this study.

\section{REFERENCES}

AZEVEDO, M.S.; DE LA CÔRTE; F.D.; BRASS, K.E. et al. The use of xylazine or acepromazine does not interfere in the lameness evaluation by inertial sensors. J. Equine Vet. Sci., v.35, p.27-30, 2014.

BAKER, S.W.; COOK, A.; BINNS, D.J. The effect of soil type and profile construction on the performance of cricket pitches. I. Soil properties and grass cover during the first season of use. $J$. Turfgrass Sci., v.74, p.80-92, 1998.

BROSNAN, J.T.; MCNITT, A.S.; SERENSITS, T.J. Effects of varying surface characteristics on the hardness and traction of baseball field playing surfaces. J. Turfgrass Sci. v.11, p.1-13, 2009.

BUCHNER, H.H.F; SAVELBERG, H.H.C.M.; SCHAMHARDT, H.C.; BARNEVELD, A. Head and trunk movement adaptations in horses with experimentally induced fore- and hindlimb lameness. Equine Vet. J. , v.28, p.71-6, 1996.

BURN, J.F. Time domain characteristics of hoof-ground interaction at the onset of stance phase. Equine Vet. J., v.38, p657-663, 2006.

BURN, J.F.; USMAR, S.J. Hoof landing velocity is related to track surface properties in trotting horses. Equine Comp. Exerc. Physiol., v.2, p.37-41, 2007.

CHATEAU, H.; CAMUS, M.; HOLDENDOUILLY, L. et al. Kinetics of the forelimb in horses circling on different ground surfaces at the trot. Vet. J., v.198, p.20-26, 2013.

CHATEAU, H.; HOLDEN, L.; ROBIN, D. et al. Biomechanical analysis of hoof landing and stride parameters in harness trotter horses running on different tracks of a sand beach (from wet to dry) and on an asphalt road. Equine Vet. J., v.38, suppl., p.488-495, 2010. 
CHENEY, J.A.; SHEN, C.K.; WHEAT, J.D. Relationship of racetrack surface to lameness in the thoroughbred racehorse. Am. J. Vet. Res., v.34, p.1285-1289, 1973.

CREVIER-DENOIX, N.; RAVARY-PLUMIOËN, B.; VERGARI, C. Comparison of superficial digital flexor tendon loading on asphalt and sand in horses at the walk and trot. Vet. J., v.198, p.130136,2013

GUSTAS, P.; JOHNSTON, C.; DREVEMO, S. Ground reaction force and hoof deceleration patterns on two different surfaces at the trot. Equine Comp. Exerc. Physiol., v.3, p.209-216, 2006.

KEEGAN, K.G. The lameness locator (wireless inertial sensors for detection of lameness in horses). In: CONGRESS OF THE EUROPEAN SOCIETY VETERINARY ORTHOPAEDICS AND TRAUMATOLOGY, 15., 2010, Bologna. Proceedings... Bologna: ESVOT, 2010. p.215217 Disponível em: <http://ivis.org/proceedings/ esvot/2010/la/10.pdf $>$. Acessado em 07 jan. 2014.

MAHER, O.; SNYDER, J.R. Occupation-related lameness conditions - jumping/eventing/ dressage horses. In: BAXTER, G.M. (Ed.). Adams and Stashak's lameness in horses. West Sussex: Blackwell Publishing, 2011. p.12421332.

MARSHALL, J.F.; LUND, D.G.; VOUTE, L.C. Use of a wireless, inertial sensor-based system to objectively evaluate flexion tests in the horse. Equine Vet. J., v.44, suppl., p.8-11, 2012.

MOYER, W.; SPENCER, P.A.A.; KALLISH, M. Relative incidence of dorsal metacarpal disease in young thoroughbred racehorses training on two different surfaces. Equine Vet. J., v.23, p.166-168, 1991.

MURRAY, R.C.; DYSON, S.J.; TRANQUILLE, C.; ADAMS, V. Association of type of sport and performance level with anatomical site of orthopaedic injury diagnosis. Equine Vet. J., v.38, suppl., p.411-416, 2006.
NIGG, B.M.; SEGESSER, B. The influence of playing surfaces on the load on the locomotor system and on football and tennis injuries. Sports Med.,v.5, p.375-385, 1988.

PARKIN, T.D.; CLEGG, P.D.; FRENCH, N.P. Risk of fatal distal limb fractures among thoroughbreds involved in the five types of racing in the United Kingdom. Vet. Rec., v.154, p.493-497, 2004.

PERKINS, N.R.; REID, S.W.J.; MORRIS, R.S. Risk factors for musculoskeletal injuries of the lower limbs in thoroughbred racehorses in New Zealand. New Zeal. Vet. J., v.53, p.171-183, 2005.

ROSS, M.W. Movement. In: ROSS, M.W.; DYSON, S.J. (Eds.). Diagnosis and management of lameness in the horse. Missouri: Elsevier Saunders, 2011. p.64-80.

RUNGSRI, P.K.; STAECKER, W.; LEELAMANKONG, P. Use of body-mounted inertial sensors to objectively evaluate the response to perineural analgesia of the distal limb and intra-articular analgesia of the distal interphalangeal joint in horses with forelimb lameness. J. Equine Vet. Sci., v.34, p.972-977, 2014.

SAFFIH-HDADI, K.; DÉFOSSEZ, P.; RICHARD, G.A method for predicting soil susceptibility to the compaction of surface layers as a function of water content and bulk density. Soil Till. Res., v.105, p.96-103, 2009.

SMITH, R.K.W.; ROSS, M.W.; GENOVESE, R.L. The soft tissues. In: ROSS, M.W.; DYSON, S.J. (Eds.). Diagnosis and management of lameness in the horse. Missouri: Elsevier Saunders, 2011. p.694-839.

WILLIAMS, R.B.; HARKINS, L.S.; HAMOND, C.J.; WOOD, J.L.N. Racehorse injuries, clinical problems and fatalities recorded on British racecourses from flat racing and National Hunt racing during 1996, 1997 and 1998. Equine Vet. J., v.33, p.478-486, 2001. 